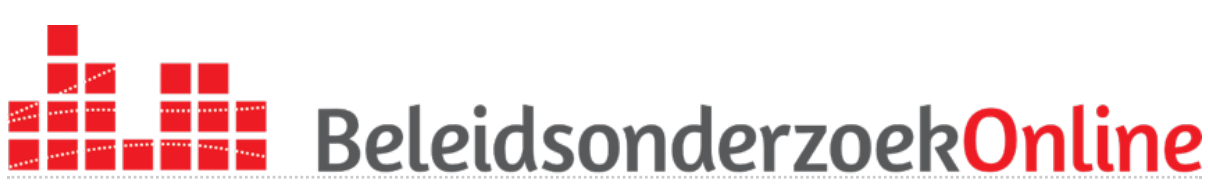

\section{Wat leert corona ons over efficiëntie?}

Jos Mevissen

\author{
Aanbevolen citeerwijze bij dit artikel \\ Jos Mevissen, 'Wat leert corona ons over efficiëntie?', Beleidsonderzoek \\ Online november 2020, DOI: 10.5553/BO/221335502020000011001
}

Effectiviteit en efficiëntie zijn de belangrijkste doelen van overheidsbeleid, zeker als we afgaan op de onderwerpen die het vaakst voorkomen in evaluaties van beleid. De huidige coronacrisis laat echter zien dat de focus op deze twee 'kernwaarden van goed beleid' niet zaligmakend is.

Kort nadat het coronavirus ook in Nederland toesloeg, groeide de kritiek op de GGD's. Er was niet snel genoeg voldoende testcapaciteit en ook duurde het te lang voordat de uitslagen van de tests bekend waren. Het bron- en contactonderzoek kon het aantal besmettingen niet bijbenen en de tests werden ook nog eens niet overal op de goede manier uitgevoerd, met het risico van besmetting, ook van medewerkers, volgens de Inspectie Gezondheidszorg en Jeugd.

Laten we deze kritiek eens plaatsen tegen de achtergrond van jarenlange bezuinigingen op de GGD's. De kosten van deze dienstverlening zijn daardoor weliswaar gedaald, waarschijnlijk zonder tot voor kort voor de gemiddelde burger duidelijk merkbare effecten op de dienstverlening. Een niet voorzien gevolg van die bezuinigingen lijkt echter te zijn dat er onvoldoende snel en effectief kon worden gereageerd op de ondersteuning die nodig is voor het opsporen en terugdringen van COVID-19-besmettingen.

Iets vergelijkbaars is te zien in de ziekenhuizen. Volgens de website van de Nederlandse Vereniging van Ziekenhuizen (NVZ) hoort '[d]e Nederlandse curatieve zorg (...) tot de beste van Europa. De toegankelijkheid is goed en de kwaliteit van de geleverde zorg is van hoog niveau en wordt nog steeds beter.' Met de effectiviteit van de zorg is dus niets mis. In de eerste golf van COVID-19-besmettingen, maar 
ook in de tweede, blijken er echter betrekkelijk weinig IC-bedden te zijn en worden intensive care behoevende patiënten zelfs naar Duitsland gebracht. Nederland heeft in vergelijking met de meeste andere Europese landen namelijk weinig IC-bedden per 100.000 inwoners. Het zijn er ongeveer vijf keer minder dan (koploper) Duitsland. Dat bespaart veel kosten in goede tijden, maar levert nu 'bezettingsproblemen' op. Niet alleen laait hierdoor al snel de discussie op wie recht moet hebben op IC-zorg, maar het leidt ook tot onvoldoende, want uitgestelde, andere behandelingen van medische zorg behoevende patiënten. Dit zijn twee corona-gerelateerde voorbeelden, maar met evenveel gemak zijn er tal van andere voorbeelden te geven, ook uit andere beleidsvelden, en tijden.

Beide voorbeelden laten zien dat effectiviteit en efficiëntie betrekkelijke begrippen zijn. Onder onderzoekers en beleidsmakers is het inmiddels dan ook een publiek geheim dat het meten van deze begrippen niet altijd gemakkelijk is, zo niet onmogelijk. Bijvoorbeeld: omdat er geen goed referentiekader beschikbaar is (efficiënter dan wat?), door een gebrek aan betrouwbare data (de vraag wordt meestal achteraf gesteld) of door onvolledige data (bijvoorbeeld doordat er geen aandacht was voor onvoorziene of afgeleide kosten), door ontbrekende aandacht voor de samenloop met ander beleid (wat wordt door het een of door het ander veroorzaakt), of door veranderingen in de beleidscontext (in hoeverre kan de effectiviteit nog wel helemaal worden toegeschreven aan de manier waarop het betreffende beleid is opgezet en uitgevoerd).

Beide casussen roepen daarenboven een vraag op die voor beleidsmakers van groot belang zou moeten zijn, maar die nooit zo expliciet gesteld wordt: aan wie komt efficiëntie van beleid ten goede?

Waren dat in het geval van GGD en ziekenhuis hun cliënten/patiënten? Of zijn dat de huidige corona-gerelateerde patiënten? Of gaat het om het personeel, de zorgverleners? De eerstgenoemden zijn het niet (hun zorg wordt - tijdelijk afgeschaald) en waarschijnlijk die zorgverleners ook niet. In de definitie van goede zorg komt de zorgverlener niet voor en uit recent onderzoek van het CNV blijkt dat met name in de zorg de werkdruk en stress door de gevolgen van de coronacrisis heel hoog zijn. Overigens ook in het onderwijs, waar, net als in de zorg, ook al vóór de coronacrisis gewezen werd op een te hoge werkdruk. Prestatiedruk en efficiënter moeten werken zijn belangrijke redenen voor werkstress en uitval door ziekte. Dat was ook al zo vóór de coronacrisis; die heeft de situatie alleen maar nog meer op scherp gezet in sectoren waar het efficiëntiestreven al enige tijd aan de orde was, niet alleen in publieke en semipublieke sectoren, maar ook in marktsectoren. 
de vraag aan wie efficiëntie van beleid ten goede komt, belangrijk is. Alleen vaststellen dat een beleidsinstrument of -ingreep efficiënt is (voor de wetgever of de uitvoerder), geeft een eenzijdig en wellicht zelfs verkeerd beeld van de efficiëntie in bredere zin. Kosten van beleid kunnen immers ergens anders vallen: bij de patiënt of cliënt, bij werknemers, bij particuliere bedrijven of bij andere onderdelen van de publieke sector. Of ze vallen op een later moment. Dit heeft een tweede consequentie voor beleidsevaluaties, namelijk dat beleidsinstrumenten niet als op zichzelf staande activiteiten beoordeeld kunnen worden. Ze maken altijd, ook onbedoeld, onderdeel uit van een complex maatschappelijk systeem.

Naschrift: wie na deze column toe is aan een wetenschappelijk artikel over corona en onderzoek, verwijs ik naar het binnenkort in Evaluation te verschijnen artikel van Ray Pawson: The coronavirus response: Boxed in by models.

Geraadpleegd (oktober 2020):

http://ieg.worldbankgroup.org/blog/rethinking-evaluation-efficiëncy https://www.ecosia.org/search? $\mathrm{q}=$ bezzuinigingen+op+GGD\&addon=firefox\&addonversion=4.0.4 https://nos.nl/artikel/2328874-waarom-nederland-vergeleken-metandere-landen-weinig-ic-bedden-heeft.html https://www.trimbos.nl/actueel/blogs/blog/mentale-gezondheidzorgprofessionals-ouderenzorg-onder-druk-tijdens-corona https://www.cnv.nl/actueel/nieuws/nieuwsdetail/cnv-onderzoekwerkdruk-hoger-dan-ooit-door-coronacrisis/ https://www.igj.nl/binaries/igj/documenten/rapporten/2020/o9/17/ggdenzijn-goed-op-weg/GGD\%27en+zijn+goed+op+weg+-+IGJrapport+over+testen+en+bron+ en+contactonderzoek+coronavirus.pdf https://nvz-ziekenhuizen.nl/kwaliteit-van-zorg 